\title{
Penanganan Kasus Kekerasan Dalam Rumah Tangga (KDRT) oleh Berencana Pemberdayaan Masyarakat dan Pemberdayaan Perempuan (BKBPMPP) Kabupaten Sleman
}

\author{
Sidiq Aulia \\ Fakultas Hukum Universitas Muhammadiyah Bengkulu \\ Email : zidex8@yahoo.com
}

\begin{abstract}
Before the existence of Law No. 23 of 2004 concerning the Elimination of Domestic Violence (UU-PKDRT), the problem of domestic violence requires handling through lines of struggle or becoming divorce cases in the Religious Courts. However, along with the improvement of the times and the community's need for the complexity of this problem, the solution to the problem of domestic violence is currently improving change, especially in terms of assisting victims of domestic violence. This paper aims to provide a scientific analysis in the field of Islamic Family Law towards the handling of Domestic Violence (Domestic Violence) Family Planning Agency for Community Empowerment and Women's Empowerment (BKBPMPP) in Sleman Regency, Yogyakarta. The data analysis method used in this paper is a qualitative research method with the consideration of deductive-inductive thinking. The results of research conducted related to domestic violence that is there are external factors caused by inequality in family relations which, are also exacerbated by other factors such as environmental and permissive cultural factors, while internal factors that can be caused by weak management to solve problems in the family. Regarding the protection and assistance that has been given to every victim of domestic violence, especially women and children, is basically an embodiment of benefit oriented to families; that is something that must exist for the upholding of human life. Domestic violence such as legal protection, health assistance for social reintegration for victims is a form that is relevant to the concept of primary benefit, especially related to human safety (an-nafs) and results (an-nasl).
\end{abstract}

Keywords: Domestic Violence, Sleman, Family Planning Agency, Community Empowerment and Women's Empowerment (BKBPMPP)

\begin{abstract}
ABSTRAK
Sebelum munculnya Undang-undang No. 23 tahun 2004 tentang Pengahapusan Kekerasan Dalam Rumah Tangga (UU-PKDRT), masalah ini kebanyakan diselesaikan melalui jalur pidana atau menjadi perkara perceraian di wilayah Pengadilan Agama. Namun, seiring tuntutan zaman dan kebutuhan masyarakat atas peliknya masalah ini, mekanisme penyelesaian KDRTsaat ini mengalami perubahan, terutama dalam hal pendampingan terhadap korban KDRT. Tulisan ini bertujuan untuk memberikan analisis ilmiah di bidang Hukum Keluarga Islam terhadap penanganan kasus Kekerasan Dalam Rumah Tangga (KDRT) Badan Keluarga Berencana Pemberdayaan Masyarakat dan Pemberdayaan Perempuan (BKBPMPP) di Kabupaten Sleman Yogyakarta. Metode analisis data yang dipakai dalam tulisan ini adalah metode penelitian kualitatif dengan kerangka berpikir deduktif-induktif. Hasil penelitian yang dilakukan tentang kekerasan dalam rumah tangga yang didapatkan dan dijabarkan dalam tulisan ini terkait keke yaitu adanya faktor eksternal di antaranya disebabkan oleh ketimpangan dalam relasi keluarga yang juga diperparah oleh faktor lainnya seperti faktor lingkungan agama dan budaya permisif, sedangkan faktor internal biasanya disebabkan oleh lemahnya manjamen emosi para pelaku kekerasan ketika menyelesaikan masalah-masalah di dalam keluarga. Adapun perlindungan dan pendampingan yang telah diberikan kepada setiap korban KDRT, terutama perempuan dan anak,
\end{abstract}


pada dasarnya merupakan bentuk perwujudan kemaslahatan yang bersifat $d$ \}aru>riyat; yaitu sesuatu yang harus ada untuk tegaknya kehidupan manusia. Kebutuhan-kebutuhan yang bersifat primer bagi korban KDRT seperti perlindungan hukum, bantuan kesehatan hingga reintegrasi sosial bagi korban merupakan bentuk-bentuk upaya yang relevan dengan konsep kemaslahatan primer tersebut, terutama berkaitan dengan menjaga jiwa (an-nafs) dan keturunan (an-nasl).

Kata Kunci : KDRT, Sleman, Badan Keluarga Berencana, Pemberdayaan Masyarakatdan Pemberdayaan Perempuan (BKBPMPP)

\section{Pendahuluan}

Perkawinan merupakan langkah awal bagi seseorang untuk membentuk keluarga yang bahagia dan kekal, karena terwujudnya rumah tangga sakinah, mawadah wa rahmahmerupakan tujuan yang sebenarnya dari perkawinan. Hal inilah yangmenjadikan perkawinan sebagai sebuah perjanjian yang sakral harus dijaga dandipertahankan eksistensinya.Akad perkawinan bukanlah perjanjian transaksional semata, melainkanikatan suci (mitsaqan ghaalizan) yang terkait erat dengan keyakinan dan keimanankepada Allah swt, atau dengan kata lain, terdapat dimensi ibadah dalam sebuah perkawinan. ${ }^{1}$ Terdapat hubungan horizontal dan vertikal antar manusia di dalam perkawinan, aspekhorizontal terdiri dari hubungan antara seorang pria dengan wanita yang mengikatkan diri, baik secara lahir maupun batin sebagai suami dan istri untukmembentuk sebuah rumah tangga, sedangkan aspek vertikal terkait hubungan

\footnotetext{
1 Amiur Nurudin dan Azhari Akmal Tarigan, Hukum Perdata Islam di Indonesia (Kencana, Jakarta, 2004), hlm. 206.
}

antara seseorang secara pribadi dengan Tuhannya dengan keyakinan dan keimanan. Kedua corak hubungan inilah yang menjadikan perkawinan sebagai sebuah ikatan suci atau akad yang bersifat luhur dan suci antara laki-laki dan perempuan mempunyai ruang lingkup tidak hanya ibadah saja tetapi juga wilayah sosial. ${ }^{2}$

KDRT sebagaimana telah disinggung di atas juga dapat menimbulkan akibatkumulatif yang tidak sederhana, seperti dapat mengurangi kepercayaan diriperempuan, menghambat kemampuan partisipasi perempuan, mengganggukesehatan perempuan, hingga mengurangi hak otonomi perempuansepertihak ekonomi, politik, sosial, dan budaya.

Pada saat yang sama, KDRT juga merupakan masalah yang cukup penting untuk disoroti di negeri ini, mengingat angka KDRT yang dilaporkan menunjukkan peningkatan

\footnotetext{
${ }^{2}$ Sudarsono, Hukum Perkawinan Nasional (Jakarta: Rhineka Cipta, Jakarta, 2005), hlm. 36.
} 
dari tahun ketahun. ${ }^{3}$ Menurut Komnas Perempuan meningkatnya KDRT bisa terjadi akibat ketidaksetaraan dan ketidakadilan gender.Kondisi ini biasanya dipicu oleh pandangan yang bias gender tentang posisi antaralaki-laki dan perempuan. Sebagai contoh, pandangan yang merendahkan perempuan berakibat pada posisi perempuan sebagai sub-ordinat dari laki-laki.

Tidak hanya itu, dari problem KDRT tersebut, pada gilirannya juga berpotensimenjadi sejumlah kekerasan lain seperti diskriminasi, marginalisasi dan beban, terutama bagi perempuan. Namun, pandangan bias terhadap posisi perempuan, terkadang harus diakui juga, memperoleh legitimasi dari paham keagamaan. Padahal, dalam hukum Islam, misalnya, jelas-jelas Islam menempatkan perempuan dan laki-laki sebagai makhluk yang setara. ${ }^{4}$

Ketimpangan relasi gender antara lakilaki dan perempuanseperti tersebut di atas, bahkan tidak jarang menjadikan kesewenangwenangan seseorang terhadap orang lain, baik menimpa perempuan atau anak-anak. Oleh sebab itu, semangat untuk mewujudkan keadilan menjadipenting untuk terus

\footnotetext{
${ }^{3}$ Muladi, Demokratisasi, Hak Asasi Manusia, dan Reformasi Hukum di Indonesia (Jakarta: The Habibie Center, 2002), hlm. 4.

${ }^{4}$ Faqihuddin Abdul Kodir dan Ummu Azizah Mukarnawati, Referensi bagi Hakim Peradilan Agama tentang Kekerasan dalam Rumah Tangga, hlm. 3.
}

dilakukandemi menghapuskan dampak dari ketimpangan relasi, menghentikankekerasan dan memberikan pemihakan kepada korban. ${ }^{5}$

Dalam hal ini, pemerintah sebenarnya telah memulai penanganan terhadap terjadinya KDRT di masyarakat. Kemunculan Undangundang Republik Indonesia Nomor 23 tahun 2004tentang Penghapusan Kekerasan dalam Rumah Tangga (UU-PKDRT) menjadi bukti atas peran pemerintah tersebut. Dalam UU ini dikatakan bahwa segala bentuk kekerasan, terutama kekerasan dalam rumahtangga, merupakan pelanggaran hak asasi manusia dan kejahatanterhadap martabat kemanusiaan serta bentuk diskriminasi yang harusdihapus. Penghapusan Kekerasan KDRTyang dimaksud adalah jaminan yangdiberikan oleh negara untuk mencegah terjadinya kekerasan dalamrumah tangga, menindak pelaku kekerasan dalam rumah tangga,dan melindungi korban kekerasan dalam rumah tangga.

Menurut pemerintah, KDRT tidak hanya sebatas tindakan kekerasan terhadap seorang perempuan atau anak, tetapi juga merupakan kejahatan yang menodai harkat dan martabat kemanusiaan. Walaupun wilayah rumah tangga adalah wilayah privat yang terikat oleh otoritas sebuah keluarga itu sendiri, namun keluarga sebagai bagian dari masyarakat,

\footnotetext{
${ }^{5}$ Ibid., hlm. 29.
} 
seharusnya sadar bahwa keluarga juga merupakan bagian dari masyarakat publik. Dengan demikian, apabilaterjadi kekerasan di dalam keluarga, publik berkewajiban menghentikan perbuatan tersebut, karena kekerasan sama halnya dengan bentuk kejahatan kemanusiaan. Bahkan, jika kekerasan itu mengakibatkan korban, publik ataumasyarakat juga mempunyai kewajiban untuk ikut campur tangan dalam membantu. ${ }^{6}$ Hal ini tentu cukup beralasan karena sebuah kekerasan justru akan mengancam dan merusak nilai-nilai dalam kehidupan manusia itu sendiri seperti keadilan, kesetaraan dan kemaslahatan.

KDRT tidak saja melanggar prinsipprinsip hukum, hak asasi manusia serta norma sosial, tetapi juga melanggar prinsip dan nilai sebagaimana inti ajaran Islam itu sendiri. Islamtidak hadir untuk merestuikekerasan yang dilakukan siapapun dalam rumah tangga, dalam bentuk dan dengan alasan apapun. Untuk itu, penguatan kesadaran keadilan harus dilakukan dan disebarkan secara terusmenerus demi mewujudkan keadilan dan menghapuskan kekerasan. Hal dapat dilakukan dengan berbagai cara seperti dengan media pendidikan atau lembaga penyadaran publik,

${ }^{6}$ Lihat pertimbangan huruf (b) dalam pembukaan dan pasal 1 ayat (2) Undang-undang Republik Indonesia Nomor 23 tahun 2004 tentang Penghapusan Kekerasan dalam Rumah Tangga. karena kerja-kerja institusi hukum seringkali tidak mencukupi jika tidak didukung oleh kesadaran hukum dalam kehidupan masyarakat. $^{7}$

Fenomena kasus KDRT dalam perkembangannya memang semakin menjadi pusat perhatian. Sebagai contoh, kehadiran Badan Keluarga Berencana Pemberdayaan Masyarakat dan Pemberdayaan Perempuan (BKBPMPP) di Slemandalam upaya penanganan kasus KDRT merupakan suatu potret peran serta pemerintah yang patut mendapatkan apresiasi, meskipun belum diketahui seberapa besar dampak positif BKBPMPP terhadap penekanan jumlah kasus KDRT yang ada di Sleman.

Untuk memberi bukti bahwa BKBPMPP sangat gelisah dengan terjadinya KDRT di Sleman, beberapa waktu yang lalu lembaga ini pernah menyatakan bahwa telah terjadi lonjakan tajam pada pelaporan kasus kekerasan dalam rumah tangga (KDRT) di Sleman. selama tahun 2018 masih cukup tinggi. Bahkan meningkat jika dibandingkan tahun 2017. Data pemkab setempat tahun 2018 terjadi 301 KDRT, sedangkan tahun 2017 terjadi 298 kasus atau meningkat 3 kasus ${ }^{8}$

${ }^{7}$ Faqihuddin Abdul Kodir dan Ummu Azizah Mukarnawati, Referensi bagi Hakim Peradilan Agama tentang Kekerasan dalam Rumah Tangga, hlm. 38.

${ }^{8}$ https://jateng.sindonews.com/read/3973/1/tahun-2018kdrt-di-sleman-capai-301-kasus-1555319090 Diakses Tanggal 03 Januari 2019. 
Menurut BKBPMPP, kasus KDRT di Sleman cukup memprihatinkan dan perlu segera diatasi. Selain jenisnya sangat kompleks, jumlahnya pun terbanyak dibanding daerah lain di Provinsi DIY. Walaupun penyebabnya belum diketahui pasti, namun kebanyakan berasal dari kalangan keluarga ekonomi lemah.Untuk mengatasinya, BKBPMPP telah melakukan berbagai macam cara di antaranya dengan melaksanakan berbagai penyuluhan tentang pembinaan keluarga sakinah dan fungsi keluarga dalam masyarakat. ${ }^{9}$

Realitas di atas menjadi hal yang kontradiktif ketika melihat selama ini Sleman atau DIY dikenal sebagai daerah yang nyaman, dan sering dijadikan rujukan tempat tinggal bagi warga lokal maupun pendatang. Sebuah daerah yang juga memenuhi indikator-indikator kota ternyaman di antaranya tata ruang yang baik, tingkat kemacetan dan polusi, minimnya kawasan kumuh dan indikator penentu lainnya. $^{10}$

${ }^{9}$ https://www.koranbernas.id/miris-301-kasus-kdrtterjadi-di-sleman, akses 12 Januari 2019.

${ }^{10}$ Hasil survey yang dilakukan oleh Ikatan Ahli Perencana Indonesia (IAP) yang dirilis pada akhir tahun 2009, misalnya, menyebut bahwa DIY menempati urutan pertama kota ternyaman di Indonesia. IAP merilis Most Livable City Index sebagai sebuah indeks tahunan yang menunjukkan tingkat kenyamanan warga kota untuk tinggal, menetap dan beraktivitas di suatu kota, yang ditinjau dari berbagai aspek perkotaan. Indeks ini dihasilkan dari survey kepada 1200 warga di 12 Kota Besar di Indonesia yaitu Medan, Jakarta,
Fenomena KDRT yang tidak berbanding lurus dengan image daerah DIY sebagaimana tersebut di atas, memberikan pertanyaan-pertanyaan mendasar yang tidak mudah untuk dijawab seperti: mengapa kasus KDRT meningkat? Apa yang terjadi di balik kenyataan tersebut? Tentunya, kedua pertanyaan ini tidak serta merta dapat dijawab dengan kajian dalam wilayah teoretis saja, tetapi juga harus dilihat secara empiris di lapangan, mengingat kompleksnya masalah KDRT dalam tatanan masyarakat. Oleh sebab itu, penyusun tertarik menjadikannya sebagai obyek penelitian lapangan dengan fokus masalah pada upaya penanganan kasus KDRT yang telah dilakukan oleh BKBPMPP kabupaten Sleman. Berdasarkan latar belakang masalah di atas, pokok masalah dalam tulisan ini adalah: Bagaimana penanganan kasus Kekerasan Dalam Rumah Tangga (KDRT)Badan Keluarga Berencana Pemberdayaan Masyarakat dan Pemberdayaan Perempuan (BKBPMPP) di kabupaten Sleman Yogyakarta? Apa saja faktor-faktor penyebab kasus Kekerasan Dalam Rumah Tangga (KDRT) di Sleman Yogyakarta? Dan Bagaimana analisis sosiologis, yuridis dan

Bandung, Yogyakarta, Semarang, Surabaya, Banjarmasin, Palangkaraya, Pontianak, Menado, Makassar dan Jayapura. Lihat http://finance.detik.com/read/2013/11/10/144948/24086 41/4/ini-dia-kota-ternyaman-di-inAdonesia, akses 16 Januari 2019. 
hukum Islam terhadap upaya penanganan kasus Kekerasan Dalam Rumah Tangga (KDRT) Badan Keluarga Berencana Pemberdayaan Masyarakat dan Pemberdayaan Perempuan (BKBPMPP) di kabupaten Sleman Yogyakarta? Tujuan tulisan ini, secara teoretis yakni untuk memberikan analisis ilmiah di bidang Hukum Keluarga Islam terhadap penanganan kasus Kekerasan Dalam Rumah Tangga (KDRT) Badan Keluarga Berencana Pemberdayaan Masyarakat dan Pemberdayaan Perempuan (BKBPMPP) di Kabupaten Sleman Yogyakarta.

\section{Metode Penelitian}

Dalam hal ini penyusun mengambil beberapa metode yang sesuai dengan jenis dan sifat yang penelitian yang dimaksud di atas. Pertama, studi dokumen atau bahan pustaka seperti buku, jurnal, laporan tahunan BKBPMPP tentang penganganan KDRT di Sleman, ataudata sejenisnya yang dipandang terkait dengan pokok masalah. ${ }^{11} \mathrm{Kedua}$, observasi yang terdiri dari pengamatan dan pencatatan dengan terhadap fenomenafenomena yang diselidiki ${ }^{12}$ yaitu tingkat kasus KDRT di kabupaten Sleman Yogyakarta melalui keterangan-keterangan tertulis dari BKBPMPP. Ketiga, wawancara, yaitu

11 Lexy J. Moleong, Metode Penelitian Kualitatif (Bandung: Remaja Rosda Karya, 2004), hlm. 149.

12 Sutrisno Hadi, Metode Research III (Yogyakarta: Andi Offset, 1989), hlm. 122. percakapan dengan maksud tertentu. ${ }^{13}$ Percakapan ini dilakukan oleh dua pihak atau lebih, yaitu antara penyusun dengan pihak BKBPMPP kabupaten Sleman Yogyakarta, terutama dengan ketua BKBPMPP dan beberapa staf yang mempunyai otoritas. Wawancara yang dimaksud untuk menemukan jawaban atas pertanyaan-pertanayaan yang dirumuskan penyusun, khususnya terkait bagaimana upaya penanganan BKBPMPP terhadap kasus KDRT di Kabupaten Sleman Yogyakarta.

\section{Analisis dan Pembahasan}

\section{A. Analisis Sosiologis-Yuridis terhadap Upaya BKBPMPP dalam Penanganan Kasus KDRT di Sleman}

Fenomena kasus kekerasan yang saat ini menjadi perhatian baik dari aktifis hingga pemerintah, jelas membuktikan bahwa keluarga, di satu pihak, mengantarkan kepada kebahagiaan seseorang menuju kebahagiaan hidup, sementara di pihak lain, keluarga sebagai ruang interaksi juga menjadi tempat yang rawan dengan terjadinya kekerasan seperti halnya KDRT atau kekerasan sejenisnya. Bentuk kekerasan ini, sesuai Pasal 5 UU PKDRT, antara lain dapat berupa kekerasan fisik, psikologis, ekonomi, seksual dan penelantaran rumah tangga. ${ }^{14}$

\footnotetext{
${ }^{13}$ Lexy J. Moleong, Metode PenelitianKualitatif, hlm. 186.

${ }^{14}$ Pasal 5 UU PKDRT.
} 
Setelah melihat bagaimana kasus KDRT di Sleman, sebagaimana yang ditanganai oleh BKBPMPP, menjadi bukti bahwa keluarga memang tidak lepas dari munculnya berbagai aktivitas ilegal yang dapat dilakukan oleh siapa saja di dalam tatanan keluarga, sehingga menimbulkan kesengsaraan atau penderitaan baik fisik, psikis dan ekonomi. Oleh sebab itu, upaya penanganan BKBPMPP mengatasi hal tersebut merupakan hal yang patut mendapat apresiasi dari masyarakat.

BKBPMPP dalam perannya menekan terjadinya kekerasan di Sleman dengan sosialisasi UU PKDRT misalnya, juga dapat dikatakan sebagai aktor yang sangat strategis untuk menciptakan ketertiban di masyarakat. Hal ini karena kekerasan baik KDRT atau bentuk lainnya yang sejenis merupakan bentuk tindakan yang tidak hanya melukai rasa kemanusiaan, tetapi juga merupakan hambatan terhadap pembangunan. Bahkan, kekerasan dapat menimbulkan akibatkumulatif yang tidak sederhana, seperti dapat mengurangi kepercayaan diriperempuan, menghambat kemampuan partisipasi perempuan, mengganggukesehatan perempuan, hingga mengurangi hak otonomi perempuansepertihak ekonomi, politik, sosial, dan budaya. Untuk itu, apabila terjadi kekerasan di dalam keluarga, publik berkewajiban menghentikan perbuatan tersebut, karena kekerasan sama halnya dengan bentuk kejahatan kemanusiaan. Selain itu, jika kekerasan itu mengakibatkan korban, publik atau masyarakat juga mempunyai kewajiban untuk ikut campur tangan dalam membantu melakukan pendampingan kepada korban. ${ }^{15}$

Korban kekerasan dalam rumah tangga pada dasarnya berhak untuk mendapatkan penanganan khusus agar tidak ada lagi kekerasan akibat faktor-faktor tersebut. Pemerintah dalam hal ini mempunyaikewajiban dan tanggungjawab dalam upaya pencegahan kekerasan dalam rumah tangga. ${ }^{16}$ Bagaimana solusi yang terbaik dalam menangani persoalan ini merupakan hal yang mutlak untuk dilakukan demi mewujudkan keluarga yang bahagia tanpa terjadi kekerasan, terutama terhadap perempuan dan anak-anak.

Munculnya UU PKDRT, yang mana merupakan upaya campur tangan pemerintah dalam menjamin hak-hak anggota keluarga jika menjadi korban kekerasan, dapat dijadikan sebagai perangkat hukum yang memadai dalam penanganan kasus KDRT. Didalamnya telah diatur mengenai pencegahan,

\footnotetext{
${ }^{15}$ Lihat UU-PKDRT: pertimbangan huruf (b) "bahwa segala bentuk kekerasan, terutama kekerasan dalam rumahtangga, merupakan pelanggaran hak asasi manusia dan kejahatanterhadap martabat kemanusiaan serta bentuk diskriminasi yang harus dihapus." Pasal 14: "...pemerintah dan pemerintah daerah sesuai dengan fungsi dan tugasmasing-masing, dapat melakukan kerja sama dengan masyarakat ataulembaga sosial lainnya."

${ }^{16}$ Pasal 12 UU PKDRT.
} 
perlindungan terhadapkorban, dan penindakan terhadap pelaku KDRT, dengan tetap menjaga keutuhandemi keharmonisan keluarga. UU ini telah menegaskan bahwa setiap warga negara berhak mendapatkan rasa aman danbebas dari segala bentuk kekerasan sesuai dengan falsafah Pancasila dan UUD 1945. UU ini juga bertujuan meminimalisir tindakan KDRT yang terjadi di masyarakat dengan semangat persamaan gender yaitu posisi hak yang sama dan sederajat antara laki-laki dan perempuan.

Berkaitan dengan hal tersebut di atas, BKBPMPP tidak hanya mempunyai peran yang strategis dalam upaya antisipasi kekerasan dalam keluarga, tetapi juga memilki peran yang signifikan dalam rangka pendampingan dan pemulihan korban akibat KDRT. Selain itu, peran lembaga ini dalam menyebarluaskan dan mensosialisasikan UU PKDRT kepada masyarakat memiliki posisi penting bagi pembangunan hukum di Indonesia, khususnya dalam hal mewujudkan efektivitas UU PKDRT dalam menekan angka kekerasan pada masyarakat.. Berdasarkan tingkat kekerasan yang ada, nampak bahwa kesadaran masyarakat untuk turut serta dalam penanganan korban kekerasan, baik sebagai korban atau pelapor, mulai memperlihatkan kemajuan dari tahun ke tahun. ${ }^{17}$

${ }^{17}$ Lihat Bab III
Tidak hanya itu, misi BKBPMPP terkait pengarusutamaan gender juga selaras dengan semangat UU PKDRT dalam upaya persamaan hak antara laki-laki dan perempuan dalam jaminan hukum, terutama apabila perempuan dan anak yang menjadi korban KDRT dalam menuntut keadilan dan perlindungan hukum. Persoalan ketimpangan gender sebagai sebab terjadinya kasus-kasus KDRT seperti di Sleman misalnya, sebagaimana diyakini juga oleh BKBPMPP, pada dasarnya bukanlah persoalan sederhana.

Munculnya kasus KDRT jelas tidak lepas dari persoalan budaya patriarkhi yang ada di dalam masyarakat, di mana pandangan budaya yang ada adalah memposisikan lakilaki lebih superior daripada perempuan. Peran BKBPMPP dalam implementasi UU PKDRT, sangat bermanfaat bagi masyarakat sebagai sarana untuk memberikan hak yang sama antara laki-laki dan perempuan, atau untuk menjamin perlindungan bagi perempuan dan anak-anak apabila menjadi korban KDRT. Hal ini penting mengingat karena selama ini, sebelum lahirnya UU PKDRT, konflik keluarga yang ada di Sleman lebih banyak diselesaikan ke dalam bentuk perkara perceraian ke pengadilan agama, bahkan menjadi perkara pidana yang ditangani oleh kepolisian. $^{18}$

${ }^{18}$ Ibid. 
Merujuk kembali tentang definisi KDRT dalam UU PKDRT yaitu "setiap perbuatan terhadap seseorang terutama perempuan, yang berakibat timbulnya kesengsaraan atau penderitaan secara fisik, seksual dan psikologis dan atau penelantaran rumah tangga termasuk ancaman untuk melakukan perbuatan, kemerdekaan secara melawan hukum dalam lingkup rumah tangga,"memang perempuan lebih diutamakan dalam penanganan KDRT, tetapi bukan berarti bahwa korban KDRT hanya perempuan. Hal ini sebagaimana yang terjadi di Sleman bahwa korban didominasi oleh perempuan dan anakanak.

UU PKDRT memang dibuat berdasarkan fenomena yang terjadi di dalam masyarakat bahwa korban KDRT adalah kebanyakan perempuan. ${ }^{19}$ Bahkan,kekerasan dalam keluargadisebut sebagai kekerasan berbasis gender. Ketika mengetahui bahwa dominasi korban KDRT adalah perempuan, upaya penanganannya harus mempertimbangkan dengan menggali pengalaman-pengalaman perempuan itu sendiri. Ini mengingat bahwa indentitas perempuan baik secara individual maupun bersamaan tidak sama. Hal ini sebagaimana teori hukum yang mengatakan bahwa setiap perempuan dan setiap orang yang berpotensi menjadi korban akan membentuk

\footnotetext{
${ }^{19}$ Ibid.
}

identitasnya sendiri, bahkan melakukan perlawanan terhadap berbagai upaya yang menindas. ${ }^{20}$ Oleh sebab itu, upaya akomodasi terhadap hak-hak korban KDRT mutlak untuk dilakukan.

Upaya tersebut sangat penting untuk memberikan perhatian terhadap perasaan malu korban atau perasaan-perasaan menghantui lainnya. Jalan pendampingan, rumah aman, rehabilitasi dan pelayanan lainnya, sebagaimana yang telah dilakukan oleh BKBPMPP,sangat relevan mengingat psikologis dan pengalaman yang berbeda-beda dari setiap perempuan dan anak-anak yang menjadi korban KDRT. Dengan fasilitas negara ini, kenyamanan perempuan dan anakanak sebagai korban untuk tidak malu ketika menanggung aib, dan menceritakan persitiwa yang dialaminya dapat diakomodir dengan baik.

Selain itu, peran BKBPMPP dalam menangani KDRT di Sleman secara tidak langsung juga merepresentasikan aktualisasi UU PKDRT di dalam masyarakat. Dalam pembukaan UU PKDRT telah dikatakan bahwa segala bentuk kekerasan, terutama kekerasan dalam rumahtangga, merupakan

\footnotetext{
${ }^{20}$ Onny Danardono, "Teori HukumFeminis; Menolak Netralitas HukumMerayakan Diference dan Anti Esensialisme"dalamSulistyowati Irianto (ed),Perempuan dan Hukum: MenujuHukum yang Berperspektif Kesetaraan danKeadilan(Jakarta:Penerbit Yayasan Obor Indonesia, 2006),hlm. 26.
} 
pelanggaran hak asasi manusia dan kejahatanterhadap martabat kemanusiaan serta bentuk diskriminasi yang harusdihapus. Penghapusan KDRTyang dimaksud adalah jaminan yangdiberikan oleh negara untuk mencegah terjadinya kekerasan dalamrumah tangga, menindak pelaku kekerasan dalam rumah tangga,dan melindungi korban kekerasan dalam rumah tangga. ${ }^{21}$

Berkaitan dengan jaminan hukum terhadap korban kekerasan, berdasarkan Pasal $28 \mathrm{G}$ ayat (1) Undang-undang Dasar tahun 1945, juga dikatakan bahwa "setiap orang berhak atas perlindungan diri pribadi, keluarga, kehormatan,martabat, dan harta benda yang di bawah kekuasaannya, serta berhak atasrasa aman dan perlindungan dari ancaman ketakutan untuk berbuat atautidak berbuat sesuatu yang merupakan hak asasi.",22 Dengan demikian, BKBPMPP sebagai bagian dari alat pemerintah dalam apaya mencegah terjadinya kekerasan dalamrumah tangga, menindak pelaku kekerasan dalam rumah tangga,dan melindungi korban kekerasan dalam rumah tangga, sebagaimana telah disebutkan dalam Bab III, sesuai dengan amanat konstitusi Republik Indonesia yang

\footnotetext{
${ }^{21}$ Lihat pertimbangan huruf (b) dalam pembukaan dan pasal 1 ayat (2) Undang-undang Republik Indonesia Nomor 23 tahun 2004 tentang Penghapusan Kekerasan dalam Rumah Tangga.

${ }^{22}$ Lihat Pasal 28 G ayat (1) Undang-undang Dasar tahun 1945.
}

memerintahkan segenap masyarakat untuk memberikan hak dan melindungi semua orang dari setiap tindakan kekerasan.

Peran BKBPMPP juga sangat erat kaitannya dengan konsep efektivitas sebuah hukum. Friedman mengatakan bahwa terdapat keterkaitan tiga sistem hukum yang saling bergerak dalam proses penegakan hukum, yaitu: 1) struktur hukum (legal structure) yang menyangkut isi dari norma/aturan hukumnya, 2) substansi hukum (legal substance) yang menyangkut sarana dan prasarana hukumnya, dan 3) budaya hukum (legal culture) yang terkait perilaku taat dan sadar hukum baik masyarakat maupun pemerintah. ${ }^{23}$

Dengan perangkat analisis ini, dapat dikatakan bahwa, pertama, pasal-pasal dalam UU PKDRT, sebagaimana yang menjadi dasar BKBPMPP dalam menjalankan fungsinya sebagai lembaga perlindungan korban KDRT, pada dasarnya merupakan wujud dari kebutuhan masyarakat-terutama jika perempuan dan anak-anak menjadi korban kekerasan-terhadap keadilan yang telah dijamin pemerintah.

Kedua, BKBPMPP merupakan sarana hukum yang dibuat pemerintah dalam rangka mewujudkan ketertiban dan efektivitas hukum di dalam masyarakat Sleman. Dengan adanya

\footnotetext{
${ }^{23}$ Lawrence M. Friedman, Sistem Hukum: Perspektif Ilmu Sosial, alih bahasa M. Khozim, (Bandung: Penerbit Nusa Media, 2009), hlm. 11.
} 
BKBPMPP, masyarakat mempunyai sarana untuk mendapatkan perlindungan hukum yang lebih. Bahkan, lembaga ini menjadi alat pengayom dan pendamai ketika terjadi kekerasan yang memakan korban di dalam keluarga. Dengan demikian, eksistensi BKBPMPP sangat penting demi mewujudkan perlindungan kepada korban kekerasan dalam kasus KDRT.

Ketiga, BKBPMPP juga menjadi alat untuk mewujudkan budaya hukum masyarakat. Kekerasan dalam kasus KDRT yang tidak mencerminkan budaya hukum yang baik, oleh BKBPMPP, dapat di tekan dengan menggunakan sosialiasasi UU PKDRT dan pelayanan terhadap korban kekerasan. Hasilnya, jika hal ini dilakukan secara terus menerus, tidak menutup kemungkinan angka kekerasan dalam kasus KDRT yang terjadi di Sleman dapat diatasi, sehingga cita-cita terwujudnya keluarga yang sejahtera dapat tercapai. Selain itu, BKBPMPP berpeluang besar dalam membentuk kesadaran masyarakat untuk menaati hukum demi keseimbangan dan ketertiban dalam tatanan masyarakat.

Dengan melihat kenyataan di atas, maka implementasi UU PKDRT untuk menekan angka KDRT dan segala bentuk kekerasan di negara ini juga merupakan wujud dari penegakan demokrasi. Demokrasi di antaranya dapat diukur dari indikator seberapa besar masyarakat dapat memperoleh akses untuk memperoleh keadilan dalam rangkamemperjuangkan hak-haknya ketika menjadi korbankekerasan. BKBPMPP dalam hal ini secara tidak langsung menjadi bagian penting dari penegak-penegak hukum yang lain dalam upaya penghapusan kekerasan dan diskriminasi. Selain itu, peran BKBPMPP juga mencerminkan bagaimana keterbukaan dan sikap pemerintah terhadap hak-hak masyarakat untukmenyampaikan persoalan-persoalan kekerasan yang menimpanya.

Hal tersebut tidak berlebihan karena KDRT merupakan fakta sosial yang bersifat universal. KDRT dapat terjadi tanpa pembedaan budaya, agama, suku bangsa, dan umur pelaku maupun korbannya. Tindak kekerasan ini dapat dilakukan oleh suami atau istri terhadap pasangan masing-masing, atau terhadap anak-anak, anggota keluarga yang lain, dan terhadap pembantu mereka secara berlainan maupun bersamaan. Perilaku KDRT ini berpotensi kuat menggoyahkan sendi-sendi kehidupan rumah tangga dengan sederetan akibat di belakangnya, termasuk yang terburuk seperti tercerai-berainya suatu rumah tangga. ${ }^{24}$

Dengan demikian, eksistensi BKBPMPP sangat penting sebagai implementasi perlindungan terhadap hak asasi manusia, dan

\footnotetext{
${ }^{24}$ Muladi,Demokratisasi, Hak Asasi Manusia, dan Reformasi Hukumdi Indonesia (Jakarta: The Habibie Center, 2002),hlm.21-23.
} 
mewujudkan masyarakat yang bebas dari diskriminasi dan kekerasan dalam keluarga. BKBPMPP juga berfungsi sebagai alat ukur seberapa jauhefektivitas hukum dan sosialisasi pemenuhan hak-hak dan keadilan hukum terhadap masyarakat telah berjalan. Hal demikian akan meningkatkan rasa percaya diri masyarakat dalam suasana kehidupandemokratis yang bermanfaat bagi kehidupannya.

B. Analisis Hukum Islam terhadap Upaya BKBPMPP dalam Penanganan Kasus KDRT di Sleman

Syari'at pada dasarnya merupakan petunjuk Allah swt untuk manusia dalam menjalankan segala aktifitas kehidupannya di dunia. Petunjuk ini tidak hanya sekedar menjadi koridor hukum, tetapi juga menjadi bagian dari penjamin kebahagiaan manusia itu sendiri. Dalam al-Qur'an juga mengisyaratkan bahwa syariat yang diturunkan oleh Allah melalui Nabi Muhammad SAW bertujuan untuk membawa manusia kepada kebahagiaan dunia dan akhirat. Ayat ini jugamengindikasikan bahwa tujuan syariat untuk mengatur kemaslahatan yang ada padakehidupan manusia. Selain itu, prinsipprinsip lainnya adalah menegakkan keadilan,tidak menyulitkan, menyedikitkan beban dan berangsur-angsur dalam prosespenerapan hukum. ${ }^{25}$

Kemaslahatan merupakan satu istilah yang paling populer ketika berbicarahukum Islam. Hal tersebut disebabkan kemaslahatan merupakan tujuan syara'(maqasid asysyari'ah) dari ditetapkannya hukum Islam. Tidak hanya itu, menurut Hasbi misalnya, kemaslahatan juga berarti jalbul manfa'ah wa daf'ul mafsadah (menarik kemanfaatan dan menolak kemudaratan). ${ }^{26}$ Adapun dasar konsep kemaslahatan, setidaknya dalam tradisi ulama, diklasifikasikan menjadi beberapa tingkatan seperti: ${ }^{27}$

1. Kemaslahatandaruriyat; yaitu sesuatu yang harus ada untuk tegaknya kehidupan manusia. Kebutuhan-kebutuhan ini yang bersifat esensial (primer) bagi kehidupan manusia. Kebutuhan esensial ini adalah memelihara agama, jiwa, akal, keturunan dan harta. Tidak terpenuhinya kebutuhankebutuhan itu akan mengakibatkan terancamnya eksistensi kelima hal pokok tersebut.

25 Jaih Mubarok, Sejarah dan Perkembangan Hukum Islam, cet. ke-3 (Bandung: Rosda Karya, 2003), hlm. 712.

26 Hasbi Ash-Shiddieqy, Falsafah Hukum Islam (Semarang: Pustaka Rizki Putra, 2001), hlm.171-182.

${ }^{27}$ Syari'at diturunkan bagi umat manusia dalam rangka mewujudkankemaslahatan(mashlahah) mereka, baik kemaslahatan di dunia maupun di akhirat. Lihat AsySya>thibi, Al-Muwafaqat fii Ushul al-Ahkam (ttp.: Da>r al-Rasyad al-Hadis\ah, t.t.), Jilid I, Juz I, hlm. 2 
2. Kemaslahatan al-hajiyat; yaitu sesuatu yang dapat menghindarkan manusia dari kesulitan bagi subjek hukum. Kemaslahatan ini tidak termasuk kebutuhan yang esensial: jika kemaslahatan ini tidak terpenuhi, maka tidak akan menimbulkan kerusakan atau mengancam eksistensi manusia melainkan hanya akan menyebabkan kesulitan. Kelompok maslahat ini sangat erat kaitannya dengan keringanan (rukhsah) dalam fikih.

3. Kemaslahatan tahsiniyat; yaitu kemaslahatan yang menopang peningkatan martabat seseorang dalam masyarakat dan di hadapan Allah swt. Namun, meninggalkan kemaslahatan ini tidak akan mengancam eksistensi manusia atau menimbulkan kesulitan, karena ia hanya bersifat sebagai pelengkap kehidupan. ${ }^{28}$

Merujuk pada klasifikasi-klasifikasi tersebut, upaya BKBPMPP dalam menangani KDRT di Sleman secara tidak langsung dapat dikatakan telah melaksanakan prinsip-prinsip syari'ah yaitu mewujudkan salah satu tingkat dari kemaslahatan di atas. Bahkan, perlindungan dan pendampingan yang telah diberikan kepada setiap korban KDRT,

\footnotetext{
${ }^{28}$ Kemaslahatan makhluk dapat tercapai apabila lima hal primer dalam hidupnya telah terjamin. Lima hal tersebut antara lain agama (ad-din), jiwa (an-nafs), akal (al'aql), keturunan (an-nasl), dan harta benda (almal).Ibid., hlm. 5
}

terutama perempuan dan anak, pada dasarnya merupakan bentuk perwujudan kemaslahatan yang bersifatd/aru>riyat; yaitu sesuatu yang harus ada untuk tegaknya kehidupan manusia.

Kebutuhan-kebutuhan yang bersifat primer bagi kehidupan manusia dalam konteks penanganan kasus KDRT oleh BKBPMPP di Sleman seperti dari perlindungan hukum, bantuan kesehatan hingga reintegrasi sosial bagi korban merupakan bentuk-bentuk upaya relevan dengan konsep kemaslahatan daruriyat, terutama dalam pemeliharaan jiwa, akal, harta dan keturunan. Dengan demikian, hal tersebut sesuai dengan tujuan-tujuan syari'at yaitu untuk mempertahankan keutuhan rumah tangga, sehingga tujuan dari pernikahan tetap terjaga tanpa adanya konflik yang berkepanjangan.

Peran BKBPMPP sangat penting untuk melestarikan keberlangsungan keluarga, mengingat selama ini penyelesaian konflik di dalam keluarga terbatas pada dua pilihan yaitu perkara perceraian atau menjadi perkara pidana. Dengan kata lain, UU PKDRT yang dikawal oleh BKBPMPP dalam mengatasi terjadinya KDRT di Sleman, menjadi terobosan penting bagi terjaminnya hak-hak korban kekerasan dalam rumah tangga secara lengkap, dengan artian kemaslahatn dalam keluarga dapat dijaga eksistensinya tanpa 
berakhir kepada perceraian atau proses hukum yang lebih berat lainnya.

Sebagaimana telah disebutkan di dalam Buku I Pasal 2 tentang dasar hukum perkawinan Kompilasi Hukum Islam (KHI), membentuk keluarga pada dasarnya terikat dengan akad yang kuat (mitsaqan galizan)yang bertujuan untuk melaksanakan ibadah kepada Allah swt. ${ }^{29}$ Dengan demikian, segala bentuk kekerasan yang mengancam keberlangsungan keluarga tidak dibenarkan atas alasan apapun. Keluarga yang diliputi kekerasan seperti KDRT adalahbentuk sikap yang bertentangan dengan Undang-undang dan hukum Islam. Untuk itu, segala sikap dan budaya masyarakat yang berpotensi menjadi penyebab maraknya kekerasan di dalam keluarga harus dirubah dengan cara pandang yang lebih adil dan manusiawi. Sebagai contoh, minimnya kesadaran keadilan cara pandang terhadap perempuan, menyebabkan banyakorang dengan mudah melakukan kekerasan terhadap perempuan. Akibatnya, kehidupan rumah tanggayang diasumsikan dibangun untuk menumbuhkan keamanan dan kedamaian, justru berbalikbagi perempuan

29 Lihat Buku I Pasal 2 tentang Dasar Hukum Perkawinan, Kompilasi Hukum Islam (KHI). menjadi tempat yang paling rentan terhadap segala bentuk kekerasan. ${ }^{30}$

Sikap saling menghargai peran dalam relasi antara suami-istri pada dasarnya tidak hanya menentukan kualitas hubungan, tetapi juga sebagai salah satu perwujudan untuk memenuhi tujuan syari'at yaitu menjaga keutuhan keluarga demi kebahagiaan. Allah swt berfirman:

"Wanita-wanita yang ditalak handaklah menahan diri (menunggu) tiga kali quru'. Tidak boleh mereka menyembunyikan apa yang diciptakan Allah dalam rahimnya, jika mereka beriman kepada Allah dan hari akhirat. Dan suami-suaminya berhak merujukinya dalam masa menanti itu, jika mereka (para suami) menghendaki ishlah. Dan para wanita mempunyai hak yang seimbang dengan kewajibannya menurut cara yang ma'ruf. Akan tetapi para suami, mempunyai satu tingkatan kelebihan daripada isterinya. Dan Allah Maha Perkasa lagi Maha Bijaksana”.

Ayat al-Qur'an ini menunjukkan bahwa hak dan kewajiban suami dan istri adalah seimbang. Maka bagi suamihendaknya memberikan hak-hak istrinya sesuai dengan kewajiban-kewajibannya dan berlaku juga sebaliknya, karena syari'at Islam dalam perannya mengatur masalah keluarga sangatlah besar yang tidak hanya mencakup relasi suami-istri saja, tetapi juga sangat terkait

\footnotetext{
${ }^{30}$ Faqihuddin Abdul Kodir dan Ummu Azizah Mukarnawat, Referensi bagi Hakim Peradilan Agama tentang Kekerasan dalam Rumah Tangga, hlm. 20.
} 
dengan tata atur untuk kemaslahatan manusia pada umumnya. ${ }^{31}$

Dalam ayat al-Qur'an lain juga disinggungperihal eksistensi perkawinanbagi kehidupan, seperti ayat berikut ini,

"Sebuah ayat yang sangat jelas memberi isyarat bahwa perkawinan harus menciptakan kedamaian, keseimbangan dan kebahagiaan. Perkawinan adalah salah satu bentuk kekuasaan Allah swt untuk menciptakan ketentraman dan kasih sayang di antara hamba-hambaNya."

Oleh karena perkawinan merupakan subsistem dari sistem sosial yang tidak berdiri di atas ruang yang kosong, ${ }^{32}$ maka keluarga sakinah adalahkondisi ideal yang harus ditopang oleh pilar-pilar yang kokoh. Perlu perjuangan sertabutuh waktu dan pengorbanan terlebih dahulu dalam mewujudkannya. Upaya BKBPMPP dalam memperjuangkan hak-hak keadilan dan rekonsiliasi korban KDRT, secara esensial, pada dasrnya telah mencerminkan semangat keislaman yang sesuai dengan ayat-ayat di atas.

Upaya BKBPMPP dalam mendampingi dan melayani korban KDRT juga dapat dikatakan sangat erat kaitannya konsep

\footnotetext{
${ }^{31}$ Mahmus as-Shabba>gh, Tuntunan Keluarga Bahagia Menurut Islam, alih bahasa Baharuddin Fannani, cet. ke-3 (Bandung: Rosdakarya, 1993), hlm. 57.

${ }^{32}$ AchmadMubarok, Psikologi Keluarga dari Keluarga Sakinah HinggaKeluarga Besar (Jakarta: Bina Rena Pariwara, 2005), hlm. 10.
}

maqasid asy-syari'ah(tujuan hukum), ${ }^{33}$ walaupun secara normatif UU PKDRT yang dijadikan pedoman BKBPMPP selama ini merupakan produk hukum nasional yang jelas berasal dari kebutuhan masyarakat akan keadilan. Tentang ini, meminjam teori Jaseer Auda, cara pandang yang luas tehadap hukum Islam pada esensinya merupakan suatu sistem keharusan di zaman kontemporer, karena tantangan hukum Islam bukan saja terkait dengan internal umat Islam sendiri, tetapi juga sejauhmana ajaran Islam mampu memberikan kontribusi bagi peradaban modern. Lebih lanjut, menurut Jaseer, setiap aturan yang mengatasnamakan keadilan dengan ketidakadilan, kedamaian dengan pertengkaran, kebaikan dengan keburukan, kebijakan dengan kebohongan adalah aturan yang bertentangan dengan syari'ah, meskipun hal itu diklaim sebagai tafsiran yang benar. ${ }^{34}$

\footnotetext{
${ }^{33}$ Pembahasan tentang maqasid asy-syari'ahpada dasarnya telah dilakukanoleh paraulama sejak masamasa awal perkembangan ushul fiqh. As-Sya $>$ tibi $>(w$. 790 H./1388 M.), seorang yuris Islam dari Andalusia, merupakan ulama yang paling berjasa dalam membuat prinsip maqasid asy-syari'ahtersebut menjadi sebuah rumusan yang lebih komprehensif dan sistematis. Pemikirannya yang menguraikan maqasłid asysyari'ahsecara panjang lebardapat ditemukan dalam karya monumentalnyaal-Muwafaqat fii Us\}ul alAhkam(Beberapa Konsensus dalam Dasar-dasar Hukum). Lihat Rasyid Ahmad, "prawacana" dalam Muhammad Khalid Masud, Filsafat Hukum Islam, alih bahasa Ahsin Muhammad (Bandung:Penerbit Pustaka, 1996), hlm. v-vi

${ }^{34}$ Jasser Auda, Maqasid al-Shari'ah as Philosophy of islamic Law; A Systems Approach (London: the International Institut of Islamic Thougth, 2007), hlm. xxi.
} 
Dengan demikian, penghapusan kekerasan yang bertujuan untuk mewujudkan keadilan dan kebahagiaan dunia dan akhirat, sebagaimana implementasi UU PKDRT oleh BKBPMPP bagi korban KDRT, merupakan suatu hal yang selaras dengan kosep maqasid asy-syari'ahyaitu diterapkannya sebuah aturan untuk menciptakan kebahagiaan manusia, terutama berkaitan dengan harus terjaganya kebutuhan primer manusia seperti menjaga jiwa (an-nafs) dan keturunan (an-nasl).

BKBPMPP juga telah menunjukkan kepeduliannya terhadap perlindungan keluarga, pendidikan, menjaga nilai-nilai kemanusiaan, menjunjung HAM, prinsip demokrasi hingga mengutamakan kepedulian sosial yang berkaitan dengan kesejahteraan manusia. Hubungan keluarga dengan hal-hal penting seperti prinsip demokrasi, HAM dan sarana kesejahteraan manusia ini, keberadaannya harus dijaga demi mewujudkan tujuan-tujuan disyari'atkannya hukum perkawinan dalam Islam. Hal ini sebagaimana dalam pandangan Islam bahwa, dalam kaitannya dengan relasi suami-istri, kekerasan baik dalam keluarga atau wilayah lainnya merupakan hal yang tidak dibenarkan, karena setiap manusia memiliki hak dan kewajibannya yang harus dihormati dan dijaga.
Hal tersebut di atas karena KDRT pada dasarnya merupakan kejahatan yang menodai harkat dan martabatkemanusiaan. Meskipun wilayah rumah tangga adalah wilayah privat, keluarga sebagai bagian dari masyarakatjuga merupakan bagian dari masyarakat publik. Untuk itu, apabilaterjadi kekerasan di dalam ranah manapun, termasuk di dalam keluarga, hal ini sudah masuk kedalam wilayah publik karena merupakan bentuk kejahatan kemanusiaan. Artinya, publik ataumasyarakat juga mempunyai kewajiban untuk ikut campur tangan.

Dikeluarkannya UU PKDRT yang menjadi legitimasi negara untuk menghapuskan segala bentuk kekerasan, menjadi bukti bahwaKDRT tidak lagi bisa dianggap sebagai masalah privasi keluarga yang tidak bisa diganggu gugat,melainkan telah menjadi tanggung jawab masyarakat dan negara untuk turut campur menghentikannya. ${ }^{35}$ Lebih dari itu, karena kekerasan merupakan bentuk kejahatan yang bisa mengancam dan merusak nilai-nilai yangdibangun oleh ajaran agama seperti keadilan, kesetaraan, kemaslahatan, dan kerahmatan. KDRT tidak hanya melanggar prinsip-prinsip hak asasi manusia, hukum, norma dan tata kesusilaan, tetapi juga melanggar prinsip,nilai, dan ajaran

\footnotetext{
${ }^{35}$ Faqihuddin Abdul Kodir dan Ummu Azizah Mukarnawat, Referensi bagi Hakim Peradilan Agama tentang Kekerasan dalam Rumah Tangga, hlm. 37.
} 
Islam. Untuk itu, penguatan kesadaran hukum harus dilakukan dan disebarkan secara terusmenerus dengan berbagai media pendidikan dan penyadaran publik, karena efektifnya hukum juga tergantung oleh kesadaran dalam kehidupan masyarakat. ${ }^{36}$

Perlu diketahui pula, Islam tidak membedakan eksistensi antara laki-laki dan perempuandalam kapasitasnya sebagai hamba Allah, khalifah, dan perjanjian primordialdengan Allah. Islam juga tidak membedakan antara laki-lakidan perempuan untuk memperoleh kesempatan kerja dan meraih prestasi yangsetinggi-tingginya pada bidang-bidang yang dibenarkan agama. Semua manusia diberikan kesempatan dan hak yang sama sehingga antaralaki-laki dan perempuan berkompetisi secara sehat, tanpa mengabaikan kodratmereka masing-masing. ${ }^{37}$ Untuk itu, segala bentuk diskriminasi atau kekerasan terhadap perempuan dan anak yang mengatasnamakan agama, adalah pemahaman yang keliru dan harus diluruskan.

BKBPMPP dalam konteks di atas, sangat berperan penting dalam rangka merubah cara pandang agama yang sempit pada masyarakat menuju paham agama yang toleran, sehingga terbangun sikap saling

\footnotetext{
${ }^{36}$ Ibid., hlm. 38.

${ }^{37}$ Hamid Laonso dan Muhammad Jamil, Hukum Islam Alternatif Solusi terhadapMasalah Fiqh Kontemporer (Jakarta: Restu Ilahi, 2005), hlm.77.
}

menghargai hak dan kewajiban antara laki-laki dan perempuan, terutama dalam konteks relasi keluarga. Dengan sikap seperti ini, KDRT secara perlahan tidak perlu terjadi di dalam tatanan masyarakat Indonesia. Sebagaimana ayat al-Qur'an berikut ini, karena KDRT sebagai bagian dari bentuk kejahatan juga akan berpotensi mengantarkan pelakunya kepada kemudaratan, bahkan pelakunya terancam oleh hukum syari'at.

"Sesungguhnya orang-orang yang
mendatangkan cobaan kepada orang-
orang yang mukmin laki-laki dan
perempuan kemudian mereka tidak
bertaubat, maka bagi mereka azab
Jahannam dan bagi mereka azab
(neraka) yang membakar"

Bahkan, menurut ajaran Islam bahwa yang dinamakan kekerasan di dalam lingkup keluarga dilarang keras untuk dilakukan karena akan menciderai kemanusiaan seseorang. Hal ini sebagaimana Hadis berikut

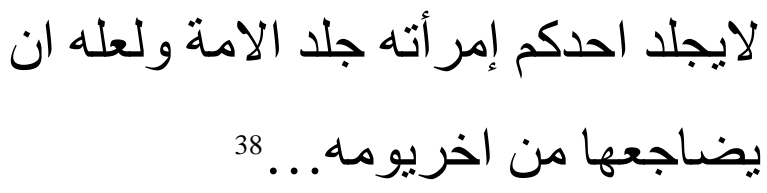

Untuk menghindari bahaya KDRT sebagaimana isyarat ayat al-Qur'an dan Hadis di atas, suami istri perlu menerapkan sistem keseimbangan peran masing-masing. Artinya, suami istri mampu bertanggung jawab dalam

\footnotetext{
${ }^{38}$ Ibnu Majah, Sunan Ibnu Majah(Beirut: Dār el-Fikr, t.t.), HadisNo. 1983, hlm. 246.
} 
posisinya masing-masing dalam tugas hidup sehari-hari demi terciptanya kebahagiaan. Sedangkan untuk mengantisipasi terjadinya konflik, paling tidak, keduanya harusmempunyai landasan yang kuat termasuk pemahamannya terhadap ajaranagama. Selain itu, faktor-faktor penting yang diperlukan untuk membentuk keluarga yang bahagia adalahterpenuhinya kebutuhan ekonomi, kebutuhan seksual, saling pengertian, dapatmemahami perbedaan dan berpegang teguh pada agama. ${ }^{39}$

\section{Penutup}

Kebutuhan-kebutuhan yang bersifat primer bagi kehidupan manusia dalam konteks penanganan kasus KDRT oleh BKBPMPP di Sleman seperti dari perlindungan hukum, bantuan kesehatan hingga reintegrasi sosial bagi korban merupakan bentuk-bentuk upaya yang relevan dengan konsep kemaslahatan dalam Islam, terutama dalam perwujudan kemaslahatan yang bersifat daruriyat seperti berkaitan dengan pemeliharaan jiwa, akal, harta dan keturunan. Dengan demikian, hal tersebut sesuai dengan tujuan-tujuan syari'at yaitu untuk mempertahankan keutuhan rumah tangga, sehingga tujuan dari pernikahan tetap terjaga tanpa adanya konflik yang berkepanjangan.

\footnotetext{
${ }^{39}$ Ibnu Rasyid, Mahligai Perkawinan (Pekalongan: CV. Bahagia, 1989), hlm. 75.
}

\section{Daftar Pustaka}

\section{Buku}

'Asyur, Muhammad al-Tha>hir, bin, Maqasid asy-Syari'ah al-Islamiyyah, Malaysia: Dar al-Fajr, 1999.

Abdul Kodir, Faqihuddin dan Ummu Azizah Mukarnawati, Referensi bagi Hakim Peradilan Agama tentang Kekerasan dalam Rumah Tangga, Jakarta: Komnas Perempuan RI , 2008.

Afifah, Zuni, "Pandangan Santri Nurul Ummah terhadap Kekerasan Dalam Rumah Tangga menurut UU No. 23 tahun 2004." Skripsi tidak diterbitkan, S1 Jurusan Al-Ahwal asy-Syakhsiyyah Fakultas Syari'ah dan Hukum, Universitas Islam Negeri Sunan Kalijaga Yogyakarta (2009).

Al-Faruqi, Isma'il Raji, Tauhid, terj. Astuti, cet. ke-2, Bandung: Pustaka Pelajar, 1995.

Ali, Zainuddin, Metode Penelitian Hukum, Ed. 1, Cet. 2, Jakarta: Sinar Grafika, 2010.

Auda, Jasser, Maqasid al-Shari'ah as Philosophy of Islamic Law; A Systems Approach, London: The International Institute of Islamic Thought, 2007.

Amiur Nurudin dan Azhari Akmal Tarigan, Hukum Perdata Islam di Indonesia (Kencana, Jakarta, 2004),

Sudarsono, Hukum Perkawinan Nasional (Jakarta: Rhineka Cipta, Jakarta, 2005),

Irianto, Sulistyowati (ed), Perempuan dan Hukum: Menuju Hukum yang Berperspektif Kesetaraan dan Keadilan, Jakarta: Penerbit Yayasan Obor Indonesia, 2006 


\section{Jurnal}

Ardian,"Peran Polda Daerah Istimewa Yogyakarta dalam Penegakan Hukum Tindak Pidana Kekerasan Dalam Rumah Tangga." Jurnal al-Ahwal Fakultas Syari'ah dan Hukum Universitas Islam Sunan Kalijaga Yogyakarta (2013).

Pramono, Ahdiat, "Akibat Perceraian yang disebabkan Tindak Kekerasan Penganiayaan terhadap Isteri (Studi Kasus di Pengadilan Agama Surakarta)." Tesis. Program Magister S-2 Kenotariatan Pascasarjana Universitas Diponegoro Semarang, (2007

\section{Website}

http://finance.detik.com/read/2013/11/10/1449 48/2408641/4/ini-dia-kota-ternyaman-diinAdonesia, akses 16 Januari 2014.

https://jateng.sindonews.com/read/3973/1/tahu n-2018-kdrt-di-sleman-capai-301-kasus15553190901

https://www.koranbernas.id/miris-301-kasuskdrt-terjadi-di-sleman, 